INTERNATIONAL JOURNAL OF MULTIDisciplinARY RESEARCH AND ANALYSis

ISSN(print): 2643-9840, ISSN(online): 2643-9875

Volume 05 Issue 02 February 2022

DOI: 10.47191/ijmra/v5-i2-41, Impact Factor: 6.072

Page No. 533-541

\title{
The Impact of Parental Child-Rearing Style on School Attendance
}

\author{
Alfred Dorgbetor \\ Akatsi College of Education, Ghana
}

\begin{abstract}
The study was a descriptive survey carried out to find the effect of parental child-rearing style on school attendance of Junior High School students in the Sefwi Wiawso Municipality. A sample of 340 students reported on their parents' parenting style using Parental Authority Questionnaire. A record of school attendance was taken from students' school attendance registers from sampled schools. Multiple Regression analysis was conducted to assess the effects of parenting style school attendance. The result showed that authoritarian parenting style predicted negatively with school attendance. Also, the authoritative parenting style has a positive prediction for school attendance. Implications, limitations, and future research opportunities are discussed. Parenting style played an important role in influencing the level of a child's school attendance.
\end{abstract}

KEYWORDS: Parenting Style, Authoritative, Authoritarian, Permissive, School Attendance

\section{INTRODUCTION}

Nothing stirs adults' emotions or captures their attention quite like the birth of a child (Bornstein, 2002). Psychologists, sociologists, educators, and policymakers who study children and development have long viewed parenting and the family as the most significant influence on the developing child (Bjorklund, Yunger \& Pallegrin, 2002). Parenting is critical not only for humans, but also for the survival of numerous animal and bird species. In the long-debated and still contentious nature-nurture dichotomy, parenting has traditionally been viewed as a significant source of environmental variability (Bjorklund et al., 2002). As a result, the parents' role becomes paramount in the existence of any progeny.

Parenting practise refers to the culturally prescribed routines of child care and child training that the child's caregiver follows (Edward, Knoche, Aukrust \& Kim, 2005). The significance of this explanation of parenting practises is that almost every society has a set of culturally accepted routines for training children. As a result, these practises are prevalent among all parents in society. Parents, on the other hand, defer to their culture's standards when it comes to child rearing. Thus, the distinction in child rearing is in the manner in which these culturally established practises are implemented. In Ghana, for example, it is considered acceptable for children to perform household chores such as dishwashing and fetching water for domestic use. Every parent wishes to adhere to these practises to the letter in order to avoid their children being labelled as wayward in society. The question that occasionally crosses one's mind is why some children of different parents in the same community are regarded as well behaved while others are not. Certainly, the approach to child rearing is the answer. It is a method of child rearing that increases the likelihood of a child developing into the acceptable and capable individual society desires (Alvy, 2007).

The approach to child rearing varies according to the parent's style, from emotional support to verbal give-and-take situations. According to Lightfoot, Cole, and Cole (2009), parenting style is a term that refers to parents' behaviours and strategies for controlling and socialising their children. The term originated with Baumrind's (1971) study of parents and children, which concluded that parents raise their children in one of three styles. Darling and Steinberg (1993) assert that the distinction between parenting style and parenting practise is in the developmental outcomes sought. Darling and Steinberg argue that parenting practise has a direct effect on specific child developmental outcomes, whereas parenting style has a moderating effect on the relationship between parenting practise and developmental outcomes. Thus, child rearing practises must be moderated in order to provide the desired socialisation goals and competencies that boost a child's self-esteem and, as a result, interest in school attendance.

In recent years, some parents have been confronted with the daunting task of balancing career and the responsibility of raising children who exhibit societally acceptable behaviours. This rather difficult situation forces parents to relegate their critical role of parenting to a level that begs for culturally - established forms of child rearing. Naturally, interactions between mothers and 


\section{The Impact of Parental Child-Rearing Style on School Attendance}

children provide the rewarding security necessary for children to begin developing their self-concept and self-identity. Additionally, the situation in Sefwi - Wiaws appears to indicate that some parents prioritise their career over their child's developmental needs. While it is every parent's joy to see their child develop into a competent and capable member of society, there is no such magic wand. The only magic bullet capable of transforming a teenager's life would be a pill laced with self-esteem (Katz, 2000). As a result, parents face an extremely demanding and difficult task of child rearing. Unfortunately, children do not arrive in the world with a manual to guide them (Reynolds, 2010). Child rearing is a difficult and emotional experience that every parent must endure in order to shape the child's future image (Ipatenco, 2010). Negative beliefs about ourselves can develop as a result of our inherited experiences from childhood. According to experts, the parenting style adopted by parents has an effect on their children's emotional, cognitive, and behavioural development (Maier, 2012). To put it mildly, the emotional impact of parenting style on the child can be devastating. This may result in a child's low or high self-esteem and may have an effect on his or her academic achievement as a result of poor school attendance.

Regular attendance at school is a critical factor in academic achievement. Every parent wishes for their children to succeed in school. The child's attitude toward school can be either positive or negative. The ability of a child to attend school regularly or irregularly is highly dependent on his or her motivation. The motivation of a child can be intrinsic or extrinsic, depending on the motivation. Internal motivation, according to Grolnick and Farkas (2002), is self-regulated. To activate this internal motivation, the child requires autonomy, competence, and relationships with other significant individuals. To develop autonomy in a child, positive self-experience is required that fosters the belief that one can initiate one's own action. Competence, on the other hand, is the sense of being effective in one's interactions with one's environment. The desire to feel connected to significant others is a critical factor in intrinsically motivating the child (Grolnick \& Farkas 2002). According to Rumberger (1995), motivation can also come from factors such as the school environment's quality, the teacher-student relationship, and the staff's quality and effectiveness. In light of these motivational issues, the parent's ability to effectively moderate the development of competence, aided by the provision of emotional autonomy, will enable the child to achieve the self-regulation Grolnick and Farkas discussed.

Reid (2008) observed that students who face domestic difficulties are more likely to dislike school than their peers who receive parental love and support. Self-experience and a lack of concept in children may be the result of a poor home environment. These factors may contribute to behavioural and psychological difficulties. Students who have negative self-experiences are more likely to miss school than students who have positive self-experiences. Teasley (2004) asserted that the family structure, parent-child relationship, and parental school involvement all played a role in school absenteeism. The child must be motivated to succeed in school.

\section{Parenting}

Parenting is important not only to humans, but central to the survival of many species of animals and birds. In an attempt to investigate the history of parenting, according to French (2002), the Greeks were the first to consider parenting and child development systematically. He added, however, that the Greeks and Romans viewed parenting as the result of nurturing, as well as the requirement for parents to invest time, energy, and resources appropriate to the child's developmental stage. In the longdebated and still contentious nature-nurture dichotomy, parenting has traditionally been viewed as a significant source of environmental variability (Bjorklund et al., 2002). Rothbaum, Pott, Miyake, and Moreili (2000) observed that parents are expected to respond sensitively to their children's needs in response to an explicit signal from the child. This, they stated, could be due to cultural influences. As a result, the parents' role becomes paramount in the existence of any progeny. This section will discuss human parenting. The survival of an infant is entirely dependent on its parents. According to the Microsoft Encarta dictionary for students (2009), parenting is the experiences, skills, characteristics, and responsibilities associated with being a parent and teaching and caring for a child. Parenting is a sacred and permanent responsibility that parents prepare their children for (Bornstein, 2002). It is the primary functional state of a human being throughout his or her life. Bjorklund et al. (2002) argued that parenting in humans, unlike other species, has been elevated to a new level due to our children's extended period of immaturity in comparison to other species. A parent's role is to guide and nurture all aspects of their child's development, including social, emotional, cognitive, and educational development. Parents serve as the primary role models and educators, guidance counsellors, and nurturers for their children.

\section{Authoritarian Parenting Style}

According to Baumrind, authoritarian parents are demanding and directive but unresponsive. This style is characterised by a lack of warmth, a high level of conflict, and attempts at coercive and punitive control (Rowntree, 2007). Parents are neither receptive nor warm toward their children. They place a high premium on their children's maturity, primarily because they are intolerant of selfish or inappropriate behaviour. They are obedient and concerned with their status, and expect their commands to be followed without explanation. 


\section{The Impact of Parental Child-Rearing Style on School Attendance}

\section{Authoritative Parenting Style}

The authoritative parenting style is characterised by a high degree of warmth and a high degree of exigency in the relationship between the parent and the child (Asheikh, et al., 2010). Positive or assertive control is also present, and parents have high expectations of their adolescents (Rowntree, 2007). Parents are both obnoxious and receptive. They supervise and instil clear expectations for their children's behaviour (Baumrind, 1991). Parents can be abrasive or repressive. Their method of discipline is more supportive than punitive. They desire assertive children who are also socially responsible, self-regulated, and cooperative. Children raised in this manner develop a positive image of themselves because they are given the opportunity to participate in their own education.

\section{Permissive Parenting Style}

Under the permissive parenting, the relationship between the parent and the child is characterized by high warmth and low demandingness (Darling \& Steinberg, 1993). Baumrind described parents under this parenting style as non-directional and lenient, they do not require mature behaviour, allow considerable self-regulation, and avoid confrontations with their children. Children brought up under this type of practice, have too much freedom to operate without regulation.

\section{Parenting style and School Attendance}

The family and school both contribute significantly to the socialisation and education of the child (Epstein \& Sander, 2002). The child's first education begins at home, with the parents serving as role models (Bandura 1977). There is no doubt that a symbiotic relationship exists between the school and the home, in which one's actions influence the outcome of the other. It is not for nothing that there is a strong advocacy for effective Parent-Teacher Associations (PTAs) in Ghana's Basic and Second Cycle institutions, but to foster a cordial school-home relationship in order to maximise a child's academic success. At the heart of academic success is a child's rate of school attendance. Cornville-Smith, Ryan, Adams, and Dalicandro (1998) observed that family relationships play a significant role in a child's school attendance in a study to distinguish absentee students from regular attendees. Epstein and Sheldon (2007) found that a positive school-family relationship predicted an increase in a child's daily attendance at school. The child's socioemotional adjustment in school will motivate him or her to develop the necessary interest in attending school. In a study published in 2012, Shobola, Omoregbe, and Olufemi discovered a positive correlation between pupils' school attendance and an authoritative parenting style. Brill (2009), on the other hand, found no evidence of a positive correlation between permissive parenting style and child school refusal. As Ang and Goh (2006) discovered in their investigation of Asian society to determine the effect of authoritarian parenting on children, authoritarian parenting nurtured children who were less delinquent and performed better in social competence. According to Okorodudu (2010), contrary to the widespread belief that authoritarian parenting styles are a good predictor of child delinquency, authoritarian and authoritative parenting styles cannot predict adolescent delinquency. Hocking (2008), in a study, identified factors that he termed "parentally condoned absence" as being responsible for school absenteeism. These factors included a lack of value for education, domestic problems, and inconsistent to inadequate parenting.

\section{Statement of the Problem}

Everyone needs significant others who will endorse one's selfhood, people who scaffold a sense that one's self matters and that one's efforts can produce results. Parents provide this critical environment for children to develop through the influence of parenting processes and the quality of parent-child relationships. When parents, through their style of parenting fail to satisfy this requirement for children to develop an appropriate visceral sense of the self, children are highly likely to develop low selfesteem which will consequently affect their school attendance.

Continuously, School Performance and Appraisal Meetings (SPAM) from 2009 to 2012 in the Sefwi - Wiawso Municipality pointed to absenteeism and parental irresponsibility as the main contributors to students' poor academic performance. Though some parents indicated that they help their children in their school assignments after school, the question that remains unanswered is the nature and form this assistance takes. This assistance given by these parents mostly end with the usual insults and the accusation of the lack of seriousness on the part of the child instead of giving the child the needed moral support and encouragement. The contribution of children in these meetings clearly indicate how emotionally detached some parents are with their children. Headmasters' reactions to some of the issues relating to absenteeism also point to the lack of parental support of both the child's material as well as emotional needs.

Also, Annual Reports of 2011 and 2012 from circuit supervisors in the municipality continuously highlight absenteeism and students' lack of interest in education as reasons for poor academic performance. This lack of interest, according to these supervisors, stems from the fact that some of the students do not see any prospect in their academic pursuits. The guidance and counselling office has been inundated with copious reports for possible guidance and counselling interventions. 


\section{The Impact of Parental Child-Rearing Style on School Attendance}

This study is therefore an attempt to investigate parents' style of bringing up children and how these styles affect their school attendance.

\section{PURPOSE OF THE STUDY}

In view of the problem identified, the purpose of the study was to investigate the effects of the three main parenting styles; authoritative, authoritarian, and permissive, in the Sefwi-Wiawso Municipality on the school attendance of Junior High school students.

\section{Research Questions}

The following research questions were addressed in this study.

1. What is the effect of authoritative parenting style on school attendance?

2. What is the effect of permissive parenting style on school attendance?

3. What is the effect of authoritarian parenting style on school attendance?

\section{Significance of the Study}

The study is significant in assisting parents in the selection of the appropriate style in child - rearing to give their children the needed confidence to face their developmental challenges as noted by Wolfradt, et al (2003). It will also help parents appreciate their roles in creating the right emotional climate in the home to help the child develop an acceptable self-concept and highlight the need for parents to encourage bidirectional communication between them and their children. The study will also aid parents to realize the importance of their involvement in school activities and parenting style as a contextual dimension in shaping their children academic outcomes.

\section{METHODOLOGY}

\section{Research Design}

The study followed the quantitative model of a correctional design using a cross-sectional approach. This approach is preferred over others because it allows indirect measure of the nature and rate of changes in the physical and intellectual development of samples of children drawn from a representative age group (Cohen, Manion \& Morrison, 2007).

Population

The study covered all public Junior high schools (JHS) in the Sefwi - Wiawso Municipality of the Western region of Ghana. A total population of 6,476 can be found in the 50 public JHS in the Municipality for the 2014/2015 academic years. This consisted of 3,443 male and 3,033 female. The target population for the study was the final year JHS students in public JHS schools in the Municipality. The total population of final year JHS student for the 2014/2015 academic year was 1,736 (Sefwi Wiawso Municipal Education Directorate, 2013)

\section{Sample and Sampling Procedure}

In consonance with Krejcie and Morgan (as cited in Cohen et al. 2007), a total sample size of 340 was drawn from the population of 1,736 (representing the population of final year JHS students in the Municipality for 2014/2015) using the table of random samples. There are seven circuits making up the number of schools in the Municipality. To ensure representativeness, all circuits were included in the study. This gave a total of seven strata. A simple random sampling technique procedure was then conducted within each stratum to select four schools by the lottery method. In all a total of 28 schools out of 50 (this represented $56 \%$ of public JHSs in the Municipality) were selected.

\section{Instrument}

The study is a quantitative research and questionnaire was the main instrument used for data collection. Parental childrearing style was measured using an adopted English Language version of the 30-items John Buri's Parental Authority Questionnaire (PAQ) scale. Data on self - esteem was collected using an adopted English version of Morris Rosenberg's 10-items Self - Esteem Scale (RSE) (Rosenberg, 1965). School attendance was measured using children's School Attendance Register (SAR).

\section{Pilot Testing}

The instrument was four times pilot tested at Anglican JHS Wiawso, Nana Biney JHS Dwenasi, Anglican JHS Anhwiam, and SDA JHS Wiawso, all in the Sefwi-Wiawso Municipality to evaluate its reliability and effectiveness with the local environment. A Cronbach alpha of .809 was produced for PAQ and .816 RSE scales. These alpha values indicate a strong internal consistency among items as indicated by Pallant (2005) that a value of .50 Cronbach Alpha Reliability Coefficients is good for scales with less than ten items. 


\section{The Impact of Parental Child-Rearing Style on School Attendance}

\section{Data Collection Procedure}

Questionnaire was administered by me with the assistance of trained assistants from the sampled schools. This was done based on the number of strata. Heads of sampled schools were priory informed through letters from the directorate. Date and time schedules were made to ensure the smooth flow of data collection.

\section{Data Analysis}

Statistical Package for Social Science (SPSS) version 16 was used for data analysis. Percentage and frequency distribution of data on self-esteem and school attendance were obtained using SPSS procedure. A multiple regression analysis was conducted using the SPSS procedure to establish the effect of parenting style (predictor variable) on school attendance (the criterion variables).

\section{RESULTS AND DISCUSSION}

A linear multiple regression analysis (entre method) was computed (table 1) with parenting styles entered as the predictor variable (authoritative, permissive, and authoritarian) and school attendance as the outcome variable. To once again find whether multicollonearity is a serious problem or not, the multicollonearity diagnostics were reviewed. Tolerance scores for parenting style ranged from .990 to .999 for the predictor variable. The Variance Inflation Factor (VIF) for the predictor variable was less than two (1.001 to 1.010) indicating that multicollonearity is not a serious problem.

Table 1: Multiple Regression Analysis for the Effect of Parenting Style

(Authoritative, Permissive, and Authoritarian) on School

Attendance (SA),

\begin{tabular}{|c|c|c|c|c|c|c|c|}
\hline Scales & B & $T$ & $R$ & R2 & $F$ & Tolerance & VIF \\
\hline $\begin{array}{l}\text { Authoritative } \\
\text { parenting style }\end{array}$ & .224 & 4.911 & $.471 a$ & .222 & 31.879 & .999 & 1.001 \\
\hline $\begin{array}{l}\text { Permissive } \\
\text { parenting style }\end{array}$ & .142 & 2.797 & & & & .991 & 1.009 \\
\hline $\begin{array}{l}\text { Authoritarian } \\
\text { parenting style }\end{array}$ & -.377 & -8.072 & & & & .990 & 1.010 \\
\hline
\end{tabular}

A linear multiple regression analysis (entre method) was computed (table 1) with parenting styles entered as the predictor variable (authoritative, permissive, and authoritarian) and school attendance as the outcome variable. To once again find whether multicolloneaarity is a serious problem or not, the multicollonearity diagnostics were reviewed. Tolerance scores for parenting style ranged from .990 to .999 for the predictor variable. The Variance Inflation Factor (VIF) for the predictor variable was less than two (1.001 to 1.010) indicating that multicollonearity is not a serious problem.

Table 2: The Analysis of Variance (ANOVA) Table Indicating Model Fit

\begin{tabular}{|l|l|l|l|l|l|l|}
\hline \multicolumn{2}{|l|}{ Model } & $\begin{array}{l}\text { Sum of } \\
\text { Squares }\end{array}$ & Df & Mean Square & F & Sig. \\
\hline \multirow{2}{*}{1} & Regression & 50.896 & 3 & 3 & 31.879 & $.000^{\text {a }}$ \\
\cline { 2 - 7 } & Residual & 178.810 & 336 & 336 & & \\
\cline { 2 - 7 } & Total & $\mathbf{2 2 9 . 7 0 6}$ & $\mathbf{3 3 9}$ & & & \\
\hline
\end{tabular}

a. Predictor: Authoritative parenting style, permissive parenting style, authoritarian parenting style

b. Dependent variable: School attendance.

Source: Field data (2014)

Table 2 indicates the analysis of variance (ANOVA) to test whether the model is significant at predicting the dependent variable (school attendance). The table shows that authoritative, permissive, and authoritarian parenting styles together explain school attendance $(p<0.001)$. The results therefore indicate that school attendance can significantly be predicted by parenting style. 
The Impact of Parental Child-Rearing Style on School Attendance

Table 3: Regression of School Attendance on Authoritative, Permissive and Authoritarian Parenting Styles

\begin{tabular}{|c|c|c|c|c|c|c|c|}
\hline Step1 & B & Beta & $R$ & $\mathrm{R} 2$ & $\begin{array}{l}\text { Adjusted } \\
\mathrm{R}\end{array}$ & $T$ & $\operatorname{Sig}(t)$ \\
\hline \multirow{4}{*}{$\begin{array}{l}\text { constant } \\
\text { authoritative } \\
\text { parenting style } \\
\text { permissive } \\
\text { parenting style } \\
\text { authoritarian } \\
\text { parenting style }\end{array}$} & 2.013 & & & & & 13.327 & .000 \\
\hline & .224 & .237 & & & & 4.911 & .000 \\
\hline & .142 & .135 & & & & 2.797 & .005 \\
\hline & -.377 & -.390 & $\begin{array}{l}.471 \\
a\end{array}$ & .222 & .215 & -8.072 & .000 \\
\hline
\end{tabular}

Source: field data

\section{Research Question One}

\section{What is the Effect of Authoritative Parenting Style on School Attendance?}

This research question was to investigate the extent to which authoritative parenting style affects the student's school attendance. Table 1 shows that authoritative parenting accounted significantly to school attendance $(B=.224, p<.001)$. It was significant in predicting school attendance with $(\beta=.224, t=4.911, p<0.001)$. As with the prediction of self - esteem, authoritative parenting style was again the second best predictor of school attendance with $t=.224$ at $p<0.001$. It made a positive contribution to the variance in school attendance. What this tells us is that when parents adopt authoritative style in bringing up their children, there will be a positive attitude of the children toward school attendance. The beta value .224 (Table 1) indicates that as authoritative parenting style increases by one standard deviation of .871 (Table 4), school attendance also increases by .224 standard deviation. The standard deviation of school attendance is .823 (Table 4), which indicates a change of .184 days $(.224 * .823$ ). This means that for every .823 years (approximately one year), spent by a parent on improving or practicing authoritative parenting, there would be an expected increase in school attendance of the child by .184 days a term. This prediction is true if permissive and authoritarian parenting styles are held constant. The results show a significant positive effect of authoritative parenting style on school attendance.

One can assign some reasons for this development in that authoritative parents are both high in demandingness and responsiveness and are highly connected to their children (Baumrind, 1971) emotionally. These parents recognize the contributions of their children as well as communicate more positives than negatives of their children to them. This gives the child that positive self-evaluation and the desire to achieve academically thus the intrinsic motivation to always be in school. As observed by Shobola et al. (2012) in their study of Nomadic children in Nigeria, they established a positive correlation between authoritative parenting style and school attendance. The child needs motivation from the home to be able to achieve in school (Teasley, 2004).

Table 4: The Mean and Standard Deviation of School Attendance, and Parenting Styles (Authoritative, Permissive, and Authoritarian)

\begin{tabular}{|l|l|l|l|}
\hline & Mean & Std. Deviation & N \\
\hline Self esteem & 1.97 & .807 & 340 \\
\hline School attendance & 1.97 & .823 & 340 \\
\hline Authoritative parenting & 1.80 & .871 & 340 \\
\hline Permissive parenting & 1.75 & .782 & 340 \\
\hline Authoritarian parenting & 1.84 & .852 & 340 \\
\hline
\end{tabular}

Source: field data

\section{Research Question Two}

What is the effect of permissive parenting style on school attendance?

This question sought to find out if the three typology of parenting style should stand individually, what will be the contribution of each to school attendance by the student. From Table 1, it can be deduced that permissive parenting style also 


\section{The Impact of Parental Child-Rearing Style on School Attendance}

made a significant contribution to the variance in school attendance with a beta value of $(B=.142, t=2.79, P<.005)$. With the $t$ $=2.79$ and $p<0.001$, permissive parenting style thus become the poorest predictor of school /attendance with the present sample after authoritarian and authoritative parenting styles. It positively accounted for the variance in school attendance. The beta value suggests that as permissive parenting style increases by one standard deviation of .782 (Table 4), school attendance increases by .142 standard deviation. The standard deviation of school attendance is .823 therefore this indicates a change of .117 days (.142 * .823). So for every .782 years (approximately a year), spent by a parent to improve his or her style of parenting in this direction, we expect school attendance of the child to increase by .142 days (not close to one day) in the term. This is true if the other predictor variables (authoritative and authoritarian) are held constant. The result of the current study indicates that permissive parenting style has a significant positive effect on school attendance.

Though the finding is statistically significant and positive in prediction with the current sample, there was no respondent whose score actually showed he or she was coming from a permissive parenting background. Being a good predictor with the current sample could be assigned the reason that may be due to the fact some of these children live with other relatives in the urban centers to attend school; these relative may decide to relax the rules in order not to attract" bad names" from the extended family. Another reason could be that some of these children may be confused in balancing the style of their actual biological parents and their caregivers. The present finding is however consistent with the findings of Shobola et al. (2012) among Nomadic children in Nigeria. It is also consistent with Okorodudu (2010) finding among adolescents of Delta Central Senatory District of Nigeria. The present finding is however inconsistent with the finding of Brill (2009) whose finding established a negative correlation between parents' permissive style and child school attendance. Another inconsistency is with the findings of Ang and Goh (2006) among Asian children. They argued that culture may account for their finding.

\section{Research Question Three}

\section{What is the Effect of Authoritarian Parenting Style on School Attendance?}

This research question sought to investigate the impact of authoritarian parenting style on school attendance. Table 1 indicates that authoritarian parenting style made a significant contribution to the variance in school attendance $(B=-.377, t=-$ $8.072, p<.001$ ). Consistently, with $t=-8.072$ and $p<0.001$, authoritarian parenting style is significant and thus the best predictor of school attendance among the present sample. The beta value of -.377 is an indication that authoritarian parenting style made a negative contribution to school attendance. It means that as authoritarian parenting style increases by one standard deviation of .852 (Table 4), school attendance decreases by -.377 (table 1) standard deviation. The standard deviation of school attendance of the current sample is .823 which is an indication of a change of $.310\left(.337^{*} .823\right)$. So for every .852 years (approximately one year) spent by a parent practicing authoritarian style on the child, there is the expectation that school attendance by the child would reduce by .310 days a term. This holds true if authoritative and permissive parenting styles are held constant. The current result indicates that authoritarian parenting style has a significant negative effect on school attendance.

Inconsistent parenting attitude and parents not valuing education could be contributing to the negative effect of authoritarian parenting of school attendance (Hocking, 2008). Authoritarian parents expect their orders to be obeyed without explanation (Rowntree, 2007) and because of this they sometimes condoned children absenteeism (Hocking, 2008) by ordering them to do things they think will enhance their status at the expense of the education of the child. For example the farmer in the village will prefer the child to assist more on the farm since that would enhance his or her status among great farmers in the village than encouraging that child to go to school. Children of these parents are compelled to comply because of the fear that they may be punished. Automatically, no human being wants to be overly controlled and children from Sefwi Wiawso Municipality are not different. They also expect their parents to give them some emotional support and recognition of their worth as all other children anywhere around the globe would expect from their parents, cultural dynamics notwithstanding. The child needs some level of motivation to want to achieve in school. If the parent does not show any concern for the child's emotions, that intrinsic motivation mentioned by Grolnick and Farkas (2002) would be lost on the child. So because these parents are predominantly farmers and exclusive in most case in farm settlements as well as the fact that some of them might have experienced authoritarian parenting, they do not value granting emotional freedom to children. Reid's (2008) observation that children who experience home difficulties are more prone to dislike school attendance has been confirmed by the present finding. The finding also supports the claim that poor parent - child relationship is a major contributor of absenteeism among students (Cornville et al. 1998).

\section{IMPLICATIONS AND RECOMMENDATION}

The negative results between authoritarian parenting style and school attendance called for parents' need to restructure their homes in order to give their children a positive self-acceptance outlook. Taking an excerpt from one of the statement on authoritarian parenting style that states "As I was growing up, my parents always wanted me to do whatever they asked you to 


\section{The Impact of Parental Child-Rearing Style on School Attendance}

do immediately without asking questions", for example, if a child's response to a statement like this is "strongly agree," (which, of course was the case) it tells us that such a child would never have his or her voice heard in that family. Not letting the child's voice to be heard means making the child coiled back to the state of timidity with the negative feeling that after all nobody would listen to me. This negative feeling may lead to underachievement. The implication of this to the parent is bidirectional in that the parent may not get the best out of the child and the child will equally not enjoy any emotional freedom in the family.

The implications of the study for education are three fold. The first is the link between school attendance and parenting style. This calls on policy makers to, in their attempt at eliminating or reducing the incidence of student absenteeism, fashion out policies that will bring out positive parenting outcomes. Parents can benefit from parenting programmes which could be organized in the churches, mosques, the media (print and electronic), and the national information service department. There could also be regular Parents - Teachers Association (PTA) and School Management Committees (SMC) interactions to foster a strong school - home relation as well as educate parents to improve children's attendance to school.

It is recommended that there should be programmes put in place to strengthen existing school - home relationship because any disconnection would adversely affect the child.

It is also recommended that the department of Social Welfare should put preventive intervention programmes in place to encourage parents to be more authoritative in bringing up their children than providing adhoc solutions to issues.

\section{REFERENCES}

1) Alsheikh, N., Parameswaran, G., \& Elhoweris, H. (2010). Parenting style, self - esteem and student performance in the United Arab Emirates (Electronic version). Current issues in Education, 13 (1). Retrieved on April 28, 2013 from http://cie.asu.edu/

2) Alvy, K. T. (2007). What is effective parenting? The National Effective Parenting Initiative. From www.EffectiveParentingUSA.org.

3) Ang, R. K., \& Goh, D. H. (2006). Authoritarian parenting style in Asian society: A cluster - analytic Investigation. Contemporary family therapy (Electronic version). An international journal, (1)28, 132 - 151.

4) Bandura, A. (1977). Social learning theory. Engdewood Cliffs NJ: Prentice Hall.

5) Baumrind, D. (1967). Child care practices antecedent three patterns of preschool behaviour (electronic version). Gene. Psychol. Monographs 75,43-88.

6) Baumrind, D. (1971). Current Patterns of Parental Authority (electronic version). Developmental psychology Monographs 4(2, pt.2)

7) Baumrind, D. (1991). The influence of parenting on adolescent's competence and substance use (Electronic version). Journal of Early Adolescence, 11(1), 56-95.

8) Bjorklund, D. F., Yunger, J. L., \& Pellegrin, A. D. (2002). The evolution of parenting and evolutionary approaches to child rearing. In M. H. Bornstein (Ed.). Handbook of parenting, Vol. 2: Biology and Ecology of parenting (3-30). Mahwah, NJ: Lawrence Erlbaum Associates.

9) Bornstein, M. H. (2002). Parenting Infants. In M., H., Bornstein (Ed.), Handbook of parenting, Vol. 1: Biology and Ecology of parenting (p 3-44). Mahwah, NJ: Lawrence Erlbaum Associates.

10) Brill, L. D. (2009). School Refusal: Characteristics, Assessment, and Effective Treatment: A Child and Parent Perspective (Electronic version). PCOM Psychology Dissertations. Paper 17.

11) Cohen, L., Manion, L., \& Morrison, K. (2007). Research methods in Education (6 ${ }^{\text {th }}$ ed.). London and New York: Routledge Falmer.

12) Conant, J. B. (1993). The Education of American Teachers. New York: McGraw Hill.

13) Cornville - Smith, J., Ryan, A. B., Adams, R. G., \& Dalicandro, T. (1998). Distinguishing absentee student from regular attendees: The combined influence of personal, family, and school factors (Electronic version). Journal of Youth and Adolescence, (27)5, $629-640$.

14) Darling, N., \& Steinberg, L. (1993). Parenting style as a context: An integrative model (Electronic version). Psychological Bulletin 113(3), 487-496.

15) Edward, C. P., Knoche, L., Aukrust, V., \& Kim, M. (2005). Parental Ethnotheories of child development: Looking beyond Independence and Individualism in American belief system. Faculty Publication, University of Nebraska- Lincoln.

16) Epstein, J., L. \& Sheldon, S. B. (2007). Improving student attendance through family and community involvement (Electronic version). Journal of Educational Research, 95, 308 - 318.

17) French, V. (2002). History of parenting: The ancient Mediterranean world. In M. H. Bornstein (Ed.), Handbook of parenting, Vol. 2: Biology and Ecology of parenting (p 345-576). Mahwah, NJ: Lawrence Erlbaum Associates. 
The Impact of Parental Child-Rearing Style on School Attendance

18) Grolnick, W. S., \& Farkas, M. (2002). Parenting and the development of children's self-regulation. In M., H., Bornstein (Ed.), Handbook of parenting, Vol. 5: Practical issues in parenting (pp 89 - 110). Mahwah, NJ: Lawrence Erlbaum Associates.

19) Ipatenco, S. (2010). Long-term effect of child-rearing practices. Retrieved on March 22, 2013 from www.livestrong.com/article/174042-long-term-effect-of-child-rearing-practice/

20) Katz, A. (2002). Leadin g Lads. London: Topman.

21) Maier, C. (2012). Long-term effect of child rearing practices. Retrieved on February 8, 2013, from mhttp//www.ehow.com/info_8050466

22) Microsoft Student Encarta Premium (2009). Encarta dictionary. Encarta dictionary Ink.

23) Municipal Education Directorate (2011/2012). Annual Education Report. Sefwi Wiawso. Author.

24) Municipal Education Directorate (2013). Circuit supervisors' annual Report. Sefwi Wiawso. Author.

25) Okorodudu, G. N. (2010). Influence of parenting style on adolescent delinquency in Delta Central Senatory District (Electronic version). Edo journal of counselling, (3) 1, $58-86$.

26) Pallant, J. (2005). SPSS survival Manual: step by step guide to data analysis using SPSS for Windows (Version 12) (2 ${ }^{\text {nd }}$ ed.). Alexander. Allen \& Unwin.

27) Reid, K. (2008). Causes of non - attendance: An empirical study (Electronic version). Educational Review, (60) $4,345-$ 357.

28) Reynolds,T.(2010). Different child-rearing practice. Retrieved on March 22, 2013, from http://www.ehow.com/list_7517978_different-child-rearing-practice.

29) Rosenberg, M. (1965). Society and the adolescent self-image. Princeton, NJ: Princeton University Press.

30) Rothbaum, F., Weisz, J., Pott, M. Miyake, K., \& Moreili, G. (2000), Attachment and culture: Security in the United States and Japan. American Psychologist, 55(10), 1093 - 1104.

31) Rowntree, J. (2007). Parenting and outcomes for children. London: King College

32) Rumberger, R. W. (1995). Dropping Out of Middle School: A Multilevel Analysis of Students and Schools (Electronic version). American Educational Research Journal, 32(3), 583- 625.

33) Shobola, A., Omoregbe, S., \& Olufemi, O., O. (2012). Assessment of Parenting Styles on School Attendance and Academic Performance of Nomadic Children in Selected Settlements in Nigeria (Electronic version). Journal of Educational and Social Research Vol. 2 (3), 313-320.

34) Teasley, M. L. (2004). Absenteeism and Truancy: Risk, Protection, and Best Practice Implications for School Social Workers (Electronic version). Children \& Schools, 26(2), 117-128.

35) Wolfradt, U., Hempel, S., \& Miles, J. N. V. (2003), Perceived parenting styles, depersonalization, anxiety and coping behaviour in adolescents (Electronic version). Personality and Individual Differences, 34, 521-532.

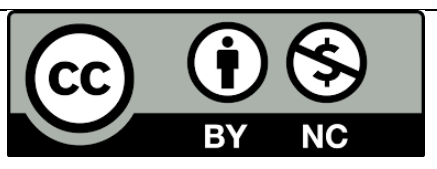

There is an Open Access article, distributed under the term of the Creative Commons Attribution - Non Commercial 4.0 International (CC BY-NC 4.0)

(https://creativecommons.org/licenses/by-nc/4.0/), which permits remixing, adapting and building upon the work for non-commercial use, provided the original work is properly cited. 